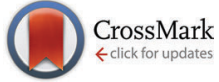

Cite this: New J. Chem., 2017, 41, 2910

Received 13th December 2016, Accepted 20th February 2017

DOI: $10.1039 / c 6 n j 03905 g$

rsc.li/njc

\section{Tetraalkynylstannanes in the Stille cross coupling reaction: a new effective approach to arylalkynes $\uparrow$}

\author{
Andrey S. Levashov, ${ }^{\star a}{ }^{a}$ Dmitrii S. Buryi, ${ }^{a}$ Olga V. Goncharova, ${ }^{a}$ Valeriy V. Konshin, ${ }^{a}$ \\ Victor V. Dotsenko ${ }^{\mathrm{ab}}$ and Alexey A. Andreev $\ddagger^{\mathrm{a}}$
}

The Stille-type cross coupling reaction with tetraalkynylstannanes was studied in detail for the first time. The reaction provides a simple and effective route towards a variety of arylalkynes. The advantages and limitations of the proposed procedure are discussed.

\section{Introduction}

For almost forty years after the pioneering research of John $\mathrm{K}$. Stille, the cross coupling reaction named after him of organic electrophiles with organostannanes has been recognized as a powerful tool for the formation of carbon-carbon bonds (see reviews ${ }^{1-5}$ ). The organotin compounds useful in the Stille reaction are mild reagents that tolerate a variety of functional groups and are the reagents of choice for delicate cross coupling syntheses of complex functionalized molecules. ${ }^{5}$ The Stille reaction has been thoroughly investigated and many advances have been made to expand both the scope and utility of this process. ${ }^{5,6}$ In contrast to other cross coupling reactions, the Stille reaction has often been found to be effective and relatively undemanding, allowing for harsher conditions, as organostannanes are relatively insensitive to moisture and oxygen. ${ }^{5}$ On the other hand, the use of organostannanes such as $\mathrm{Bu}_{3} \mathrm{SnR}$ raises problems with organotin contamination and waste. Both acute and long-term toxicities have been reported for many organotin reagents, ${ }^{7,8}$ and methods designed to limit or avoid the presence of organotin by-products in reaction products have been developed. ${ }^{9}$ In general, the toxicity of alkylstannanes decreases as the size of the alkyl groups increases $\left(\mathrm{Me}_{3} \mathrm{SnX} \sim \mathrm{Et}_{3} \mathrm{SnX} \gg \mathrm{Bu}_{3} \mathrm{SnX} \gg \mathrm{Octyl}_{3} \mathrm{SnX}\right)$ and the number of alkyl groups decreases $\left(\mathrm{R}_{3} \mathrm{SnX}>\mathrm{R}_{2} \mathrm{SnX}_{2}>\mathrm{RSnX}_{3}\right) ;{ }^{9}$ $\mathrm{R}_{4} \mathrm{Sn}$ may reveal enhanced delayed toxicity due to in vivo

\footnotetext{
${ }^{a}$ Department of Organic Chemistry \& Technologies, Kuban State University,

149 Stavropolskaya str., 350040 Krasnodar, Russian Federation.

E-mail: aslevashov@mail.ru

${ }^{b}$ Department of Chemistry, North Caucasus Federal University, 1a Pushkin str.,

355009 Stavropol, Russian Federation

$\dagger$ Electronic supplementary information (ESI) available: Spectral data. See DOI: 10.1039/c6nj03905g

\# Deceased.
}

transformation into $\mathrm{R}_{3} \mathrm{SnX} .^{10}$ However, the toxicity strongly depends on the nature of the organic group R. ${ }^{10}$ Due to the easy hydrolysis of the C(sp)-Sn bond, it is generally accepted that tetraalkynyltin compounds $(\mathrm{RC} \equiv \mathrm{C})_{4} \mathrm{Sn}$ are far less toxic than other organotin species having $\mathrm{C}\left(\mathrm{sp}^{2}\right)-\mathrm{Sn}$ or $\mathrm{C}\left(\mathrm{sp}^{3}\right)-\mathrm{Sn}$ bonds.

Another feature of tetraalkynylstannanes is their high atom economy. A practical disadvantage of the use of tin monofunctional reagents such as $\mathrm{R}-\mathrm{Sn}(\operatorname{alkyl})_{3}$ ( $\mathrm{R}$ is aryl, vinyl or alkynyl) is that a reactant of a high molecular weight is used to introduce a hydrocarbon group of a (relatively) low molecular weight, at the same time producing bulky and highly toxic triorganotin waste. Since each of the four alkynyl fragments in $(\mathrm{RC} \equiv \mathrm{C})_{4} \mathrm{Sn}$ is reactive, tetraalkynyltin compounds may be compared with sodium acetylides with respect to low molecular weight and producing only inorganic $\mathrm{Sn}(\mathrm{Iv})$ waste of low toxicity. It is noteworthy that, generally, the reactions involving organostannanes (e.g., classical Stille coupling or any other organotin-mediated process) are considered to be of a low atom economy, due to the loss of heavy and toxic tin-containing moieties. ${ }^{11}$ In other words, the $E$-factor ${ }^{12}$ (which is defined as the mass ratio of waste to desired product) of the Stille reaction with $\mathrm{R}-\mathrm{Sn}(\mathrm{alkyl})_{3}$ agents is much higher than that expected for coupling reactions with tetraalkynylstannanes, and the latter reactions could be considered as more environmentally benign. The advantages of the use of organotin compounds capable of transferring more than one organyl group are illustrated by the reactions of tetraallylstannane with electrophilic substrates. ${ }^{13}$ Tetraallylstannane is a gentle nucleophile for allylation reactions and easily reacts with imines ${ }^{14}$ aldehydes,${ }^{15,16}$ phenacyl bromide, ${ }^{17}$ other ketones $^{18}$ or carbon dioxide ${ }^{19}$ (Scheme 1). In contrast to allyltrialkylstannyl reagents which transfer only one organyl moiety out of four groups on the tin atom, from two to four allyl residues can be utilized in the case of $\mathrm{Sn}\left(\mathrm{CH}_{2} \mathrm{CH}=\mathrm{CH}_{2}\right)_{4}$. 


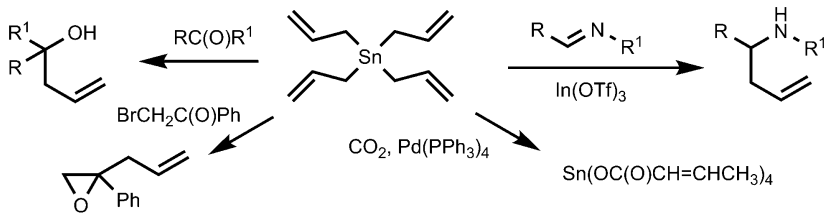

Scheme 1 Typical reactions of tetraallylstannane.

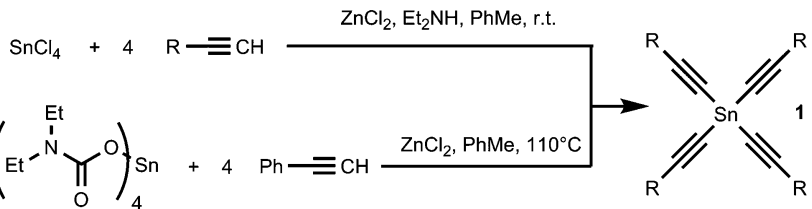

$$
\begin{aligned}
& \mathrm{R}=\mathrm{Ar}, \mathrm{n}-\mathrm{Bu} \text {, octyl, t-BuOCH} \mathrm{CH}_{2}, \mathrm{XC}(\mathrm{O}) \mathrm{OCH}_{2} \text {, etc }
\end{aligned}
$$

Scheme 2 Synthesis of tetraalkynylstannanes 1

The alkynyl fragment can be easily introduced onto a tin atom in different ways. Recently we have developed two convenient and effective methods of synthesis of tetraalkynylstannanes 1 (Scheme 2); the first is based on the direct reaction of terminal alkynes with $\mathrm{SnCl}_{4}$ in the presence of anhydrous $\mathrm{ZnCl}_{2}$ and diethylamine ${ }^{20,21}$ and the next is based on the reaction of tin tetra( $N, N$-diethylcarbamate) with phenylacetylene. ${ }^{22}$ Tetraalkynylstannanes $\mathbf{1}$ are oily or solid compounds that can be easily purified and isolated in good yields after column chromatography on a silanized silica. Also they are stable enough to be stored in a freezer for months.

While much is known about the mono-, di- and trialkynyl tin compounds, less is known about the chemistry of tetraalkynyltin compounds. Only a limited number of reactions are reported encompassing $(\mathrm{RC} \equiv \mathrm{C})_{4} \mathrm{Sn}$ as reagents (Scheme 3). Thus, the reactions with Grignard reagents were recognized as a convenient method of smooth transmetallation of tetraalkynylstannanes for the preparation of tri- and dialkynyltins..$^{23,24}$ The organoboration of $(\mathrm{RC} \equiv \mathrm{C})_{4} \mathrm{Sn}$ with trialkylboranes led to the formation of $1,1^{\prime}$ spirobistannoles $2 .^{25-28}$ Tetra(phenylethynyl)-tin was reported to be an efficient catalyst of ring-opening polymerization of L-lactide to poly(L-lactide). ${ }^{29}$ As expected for tetraalkynylstannanes 1, they may also react with acyl chlorides (4 eq.) to afford alkynyl ketones. ${ }^{30}$

To the best of our knowledge, Stille-type cross coupling reactions with tetraalkynylstannanes have not been described in the literature prior to the present work. Recently, French researchers reported ${ }^{31}$ the Stille cross coupling reaction of

$$
\begin{aligned}
& (\mathrm{R}-\mathrm{C} \equiv \mathrm{C})_{4} \mathrm{Sn}+\mathrm{R}^{1} \mathrm{MgHal} \stackrel{\mathrm{Et}_{2} \mathrm{O}}{\longrightarrow} \mathrm{R}=\begin{array}{c}
\stackrel{\mathrm{R}^{1}}{1} \\
\stackrel{1}{\dot{R}^{1}} \\
\mathrm{R}^{1}
\end{array} \\
& +(R-C \equiv c)_{3} S n-R^{1} \\
& (\mathrm{R}-\mathrm{C} \equiv \mathrm{C})_{4} \mathrm{Sn} \stackrel{\mathrm{Et}_{3} \mathrm{~B}, \mathrm{PhMe},-78^{\circ} \mathrm{C}}{\longrightarrow} \\
& (\mathrm{Ph}-\mathrm{C} \equiv \mathrm{C})_{4} \mathrm{Sn} \stackrel{4 \mathrm{AcCl}, \mathrm{Et}_{2} \mathrm{O} \text {, reflux }}{\longrightarrow} \mathrm{Ph}=\mathrm{Me}_{\mathrm{Me}}^{\mathrm{O}}
\end{aligned}
$$

Scheme 3 The known reactions of tetraalkynylstannanes 1 . di- or trialkynylstannanes with iodovinylic acids/esters, first introducing a half or a third equivalent of di- or tri-functional organotin compounds. This is the only previous report on Stille cross coupling with multi-functional C(sp)-Sn organotin compounds. In this paper, we wish to report the first example of a Stille-type cross coupling reaction of aryl halides 3 with tetraalkynyltin compounds $\mathbf{1}$.

\section{Results and discussion}

We found that tetraalkynylstannanes $\mathbf{1}$ easily react with a variety of aryl iodides and bromides under Stille conditions according to the following scheme (Scheme 4):

The tetraorganylstannanes $\mathbf{1}$ and aryl halides $\mathbf{3}$ used in the reaction are shown in Fig. 1. To prevent side reactions such as hydrolysis of stannanes $\mathbf{1}$ or oxidative couplings, the reactions
Scheme 4 The reaction of tetraalkynylstannanes 1 with aryl halides 3

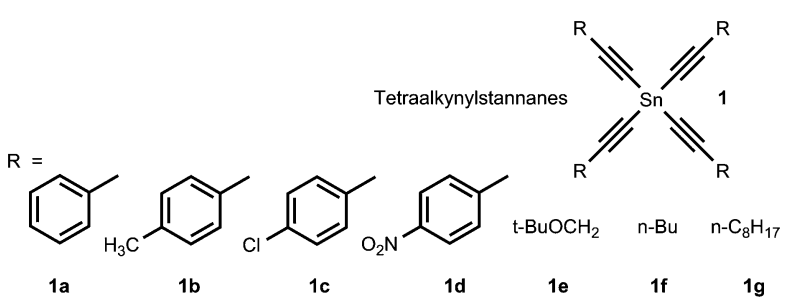

Aryl halides 3

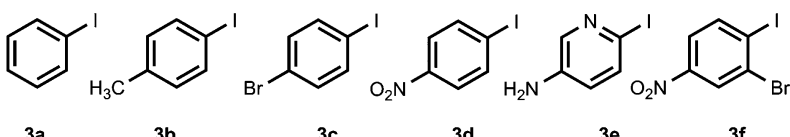

3a $3 b$

$3 c$
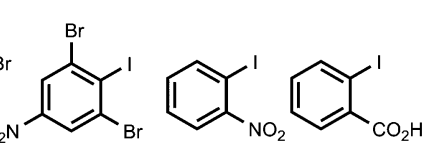

39

$3 h$

$3 \mathbf{i}$

3j

3k

31<smiles>CCOC(=O)c1ccccc1I</smiles>

$3 m$

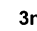

$$
\underset{\substack{\mathrm{Ar}-\mathrm{Hal} \\
\mathbf{3}}}{(\mathrm{R}-\mathrm{C} \equiv \mathrm{C})_{4} \mathrm{Sn}} \begin{gathered}
\mathrm{Pd} \text { catalyst, amine } \\
\mathbf{A r}, \mathrm{HuOAC} \text { or EtOAC }
\end{gathered}
$$

Fig. 1 The scope of stannanes 1 and aryl halides 3 used.

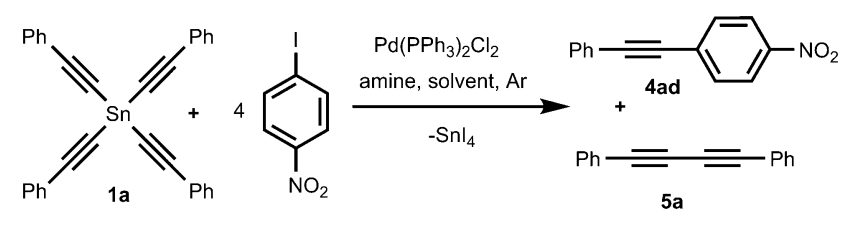

Scheme 5 The model reaction of tetra(phenylethynyl)tin 1a with $p$ nitroiodobenzene $\mathbf{3 d}$. 
Table 1 The effect of solvents and amines on the yields of aryl acetylene $\mathbf{4 a d}$ and the side product, diphenyl diacetylene $\mathbf{5} \mathbf{a}^{a}$

\begin{tabular}{|c|c|c|c|c|c|c|c|c|c|c|}
\hline \multirow[b]{2}{*}{ Solvent } & \multirow[b]{2}{*}{$T\left({ }^{\circ} \mathrm{C}\right)$} & \multicolumn{3}{|l|}{$\underline{\mathrm{Et}_{2} \mathrm{NH}}$} & \multicolumn{3}{|l|}{$\mathrm{Et}_{3} \mathrm{~N}$} & \multicolumn{3}{|l|}{ DABCO } \\
\hline & & $\begin{array}{l}\text { Yield } \\
\text { of } \mathbf{4 a d}^{b}(\%)\end{array}$ & $\begin{array}{l}\text { Yield } \\
\text { of } \mathbf{5} \mathbf{a}^{b}(\%)\end{array}$ & Time $^{c}(\mathrm{~h})$ & $\begin{array}{l}\text { Yield } \\
\text { of } 4 \mathbf{a d}^{b}(\%)\end{array}$ & $\begin{array}{l}\text { Yield } \\
\text { of } \mathbf{5 a}^{b}(\%)\end{array}$ & Time $^{c}(\mathrm{~h})$ & $\begin{array}{l}\text { Yield } \\
\text { of } 4 \mathbf{a d}^{b}(\%)\end{array}$ & $\begin{array}{l}\text { Yield } \\
\text { of } \mathbf{5} \mathbf{a}^{b}(\%)\end{array}$ & Time $^{c}(\mathrm{~h})$ \\
\hline THF & 80 & - & - & - & 20 & 22 & 5 & 50 & 6 & 1 \\
\hline $\mathrm{PhMe}$ & 100 & 55 & 10 & 7 & 27 & 14 & 5 & 87 & 8 & 0.5 \\
\hline $\mathrm{MeCN}$ & 85 & 89 & 6 & 5 & 68 & 13 & 5 & 63 & 6.5 & 5 \\
\hline Dioxane & 100 & 84 & 2 & 3 & 44 & 6 & 2 & 78 & 8 & 5 \\
\hline $\mathrm{AcOBu}$ & 100 & 98 & 2 & 2 & 85 & 2 & 5 & 86 & 5 & 2 \\
\hline $\mathrm{Et}_{3} \mathrm{~N}$ & 80 & - & - & - & 96 & 4 & 2.5 & - & - & - \\
\hline DMF & 100 & - & - & - & 89 & 9 & 2.5 & - & - & - \\
\hline
\end{tabular}

${ }^{a}$ The reaction conditions were as follows: $(\mathrm{PhC} \equiv \mathrm{C})_{4} \mathrm{Sn} 1 \mathrm{a}(20 \mathrm{mg}, 0.038 \mathrm{mmol}), 4-\mathrm{NO}_{2} \mathrm{C}_{6} \mathrm{H}_{4} \mathrm{I} 3 \mathrm{~d}(0.153 \mathrm{mmol}), \mathrm{Pd}\left(\mathrm{PPh}_{3}\right)_{2} \mathrm{Cl}{ }_{2}(5.4 \mathrm{mg}, 0.0077 \mathrm{mmol}$; $5 \mathrm{~mol} \%$ vs. 3d), amine $(0.15 \mathrm{mmol})$, and solvent $(2 \mathrm{~mL}) .{ }^{b}$ Yields were determined by GC-MS. ${ }^{c}$ Reaction time when the highest yield was achieved.

should be conducted in an inert atmosphere (argon) wherein water and oxygen are excluded. Diaryl diacetylenes 5 are by-products probably derived from the Pd-mediated Glaser-type coupling reaction occurring in the presence of trace oxygen.

A number of attempts have been made to optimize the coupling reaction conditions. We found that a variety of factors may affect the reaction outcome, such as the nature and quantity of amine additive used, the nature of the Pd catalysts and solvents, the temperature and the reaction time. As a model reaction, we examined the coupling of tetra(phenylethynyl)tin 1a with $p$-nitroiodobenzene $\mathbf{3 d}$ under different conditions (Scheme 5). First, we examined the effect of different solvents and amine additives on the yields of the target aryl acetylene 4ad, using $\operatorname{Pd}\left(\mathrm{PPh}_{3}\right)_{2} \mathrm{Cl}_{2}$ as a catalyst. The selected results are summarized in Table 1; the complete set of data is given in ESI, $\dagger$ Table S1.

As can be seen, the best results were obtained with BuOAc, EtOAc, DMF and pure $\mathrm{Et}_{3} \mathrm{~N}$ as solvents in the temperature range of $80-125{ }^{\circ} \mathrm{C}$, while the use of less polar (dioxane, PhMe) and low-boiling $\left(\mathrm{Et}_{2} \mathrm{O}\right)$ solvents resulted in lower yields of the aryl acetylene 4ad with increased amounts of the diacetylene by-product $5 \mathbf{a}$. Though only a few examples ${ }^{32-34}$ have been reported for the amine-promoted Stille reaction, we found that the presence of an amine additive is strongly required for the reaction of tetraalkynylstannanes $\mathbf{1}$ with aryl halides $\mathbf{3}$. In the absence of an amine no reaction occurs, while even trace amounts give coupling products, albeit in low yields. The nature of the amine additive as well as its amount has a dramatic effect on the reaction course, as shown in Table 2. The best results were obtained with the strong bases such as $\mathrm{Et}_{3} \mathrm{~N}, \mathrm{Bu}_{3} \mathrm{~N}, \mathrm{DABCO}$, and especially with $\mathrm{Et}_{2} \mathrm{NH}$ and $\mathrm{Pr}_{2} \mathrm{NH}$. The application of benzylic amines, piperidine, morpholine and $N$-methylmorpholine lowered significantly the yield of 4ad, whereas pyridine and ethylene diamine were found to be completely inactive. The full set of data on the amines used is given in ESI, $\uparrow$ Table S1. The amine concentration was also important and strongly influenced the reaction rate. Thus, the reaction proceeded more slowly in the presence of 1 eq. $\mathrm{Et}_{2} \mathrm{NH}$ (the yield of 4 ad reached only $66 \%$ after $5 \mathrm{~h}$ in EtOAc at $80{ }^{\circ} \mathrm{C}$ ), and quite rapidly when the amount of $\mathrm{Et}_{2} \mathrm{NH}$ was increased.
Table 2 Effects of the different amines and solvents on the yields of $\mathbf{4 a d}$

\begin{tabular}{lllllll}
\hline & \multicolumn{5}{c}{ The yield of aryl acetylene $\mathbf{4 a d}^{a, b}(\%)$} \\
\cline { 2 - 7 } Amine & \multicolumn{5}{c}{ Time $^{c}$} & \multicolumn{2}{c}{ Time $^{c}$} & Time $^{c}$ \\
& AcOBu & $(\mathrm{h})$ & PhMe & $(\mathrm{h})$ & Dioxane & $(\mathrm{h})$ \\
\hline $\mathrm{Et}_{2} \mathrm{NH}$ & 98 & 2 & 55 & 7 & 84 & 3 \\
$\mathrm{Et}_{3} \mathrm{~N}$ & 85 & 5 & 27 & 5 & 44 & 2 \\
$\mathrm{Bu}_{3} \mathrm{~N}$ & 97 & 3 & 31 & 5 & 87 & 3 \\
DABCO & 68 & 2 & 87 & 0.5 & 78 & 0.5 \\
Isophorone diamine & - & - & 54 & 7 & 86 & 9 \\
Morpholine & - & - & - & - & 54 & 1 \\
$N$-Methyl-morpholine & 12.5 & 1 & - & - & 73 & 2 \\
Pyridine & - & - & - & - & 0 & 3 \\
Piperidine & 62 & 2 & 49 & 5 & 55 & 2 \\
$\left(\mathrm{CH}_{2}\right)_{2}\left(\mathrm{NH}_{2}\right)_{2}$ & 0 & 3 & - & - & - & - \\
$\mathrm{PhCH}_{2} \mathrm{NH}_{2}$ & 41 & 5 & 43 & 5 & 56 & 5 \\
$\left(\mathrm{PhCH}_{2}\right)_{2} \mathrm{NH}$ & - & - & 11 & 3 & 26 & 5 \\
$\mathrm{Pr}_{2} \mathrm{NH}$ & 99.5 & 1 & - & - & - & -
\end{tabular}

${ }^{a}$ Yields were determined by GC-MS. ${ }^{b}$ The reaction conditions were as follows: $1 \mathrm{a}(0.038 \mathrm{mmol}), 3 \mathrm{~d}(0.153 \mathrm{mmol}), \mathrm{Pd}\left(\mathrm{PPh}_{3}\right)_{2} \mathrm{Cl}_{2}(5 \mathrm{~mol} \%$ vs. 3d), amine $(0.153 \mathrm{mmol})$ and solvent $(2 \mathrm{~mL})$ at $100{ }^{\circ} \mathrm{C} .{ }^{c}$ Reaction time when the highest yield was achieved.

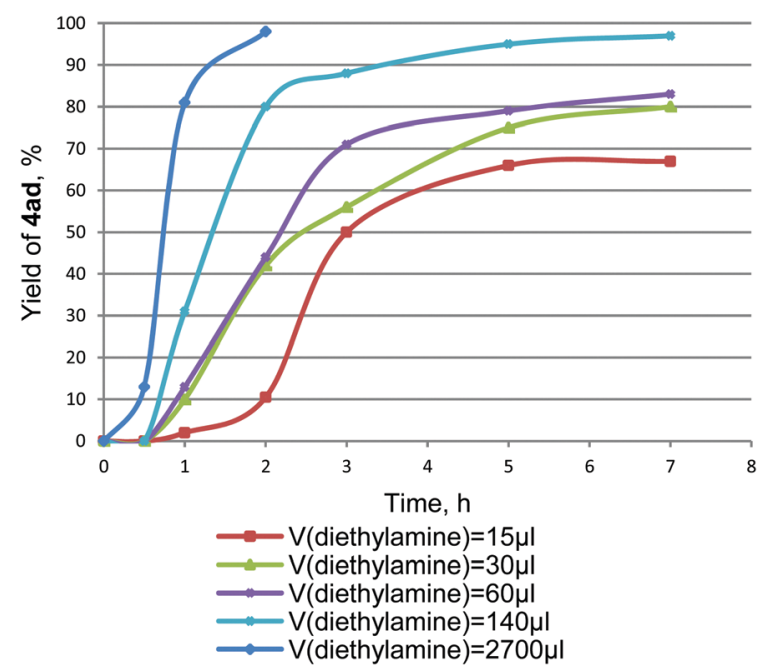

Fig. 2 The kinetics of the reaction $1 \mathbf{a}+\mathbf{3 d} \rightarrow \mathbf{4 a d}$ with different amounts of $\mathrm{Et}_{2} \mathrm{NH}$. The reaction conditions were as follows: $\left(\mathrm{PhC} \equiv \mathrm{C}_{4} \mathrm{Sn}\right.$ 1a (20 mg, $0.038 \mathrm{mmol}), 4-\mathrm{NO}_{2} \mathrm{C}_{6} \mathrm{H}_{4} \mathrm{l} 3 \mathrm{~d}(0.153 \mathrm{mmol}), \mathrm{Pd}\left(\mathrm{PPh}_{3}\right)_{2} \mathrm{Cl}_{2}$ as the catalyst $(5 \mathrm{~mol} \%$ with respect to $3 \mathrm{~d})$, AcOEt $(2.0 \mathrm{~mL}), 80{ }^{\circ} \mathrm{C}$. 
Table 3 Effects of the amine additive and its amount on the reaction outcome $^{a}$

\begin{tabular}{lrllll}
\hline & & & \multicolumn{2}{l}{ The yields $^{b}$ of } & \\
\cline { 4 - 5 } Amine & Volume $(\mu \mathrm{L})$ & $\begin{array}{l}\text { Aryl iodide } \\
\text { 3a: amine ratio }\end{array}$ & $\mathbf{4 a d}(\%)$ & $\mathbf{5 a}(\%)$ & Time $^{d}(\mathrm{~h})$ \\
\hline $\mathrm{Et}_{2} \mathrm{NH}$ & 900 & $1: 57$ & 96.4 & 1.5 & 6 \\
$\mathrm{Pr}_{2} \mathrm{NH}$ & 21 & $1: 1$ & 99.5 & 0.5 & 1 \\
$\mathrm{Pr}_{2} \mathrm{NH}$ & 105 & $1: 5$ & 99.2 & 0.8 & 1 \\
$\mathrm{Pr}_{2} \mathrm{NH}$ & 210 & $1: 10$ & 98.8 & 1.2 & 1 \\
$\mathrm{Pr}_{2} \mathrm{NH}$ & 840 & $1: 40$ & 98.9 & 1.1 & 1 \\
$\mathrm{Pr}_{2} \mathrm{NH}$ & 900 & $1: 43$ & 99.0 & 1.0 & 1 \\
$\mathrm{Pr}_{2} \mathrm{NH}$ & 1000 & $1: 47$ & 98.3 & 1.7 & 1 \\
$\mathrm{Bu}_{3} \mathrm{~N}$ & 36 & $1: 1$ & 75.7 & 2.0 & 4 \\
$\mathrm{Bu}_{3} \mathrm{~N}$ & 182 & $1: 5$ & 99.5 & 0.5 & 1 \\
$\mathrm{Bu}_{3} \mathrm{~N}$ & 640 & $1: 10$ & 99.5 & 0.5 & 1 \\
$\mathrm{Bu}_{3} \mathrm{~N}$ & 900 & $1: 25$ & 83.7 & 9.2 & 4 \\
$\mathrm{TMEDA}^{c}$ & 23 & $1: 1$ & 95.0 & 1.5 & 4 \\
$\mathrm{TMEDA}$ & 115 & $1: 5$ & 97.7 & 2.3 & 1 \\
$\mathrm{TMEDA}$ & 229 & $1: 10$ & 97.2 & 2.8 & 1 \\
TMEDA & 920 & $1: 40$ & 97.3 & 2.7 & 1 \\
TMEDA & 1000 & $1: 43$ & 94.0 & 6.0 & 1
\end{tabular}

${ }^{a}$ Unless otherwise stated, the conditions were as follows: $1 \mathrm{a}(0.038 \mathrm{mmol})$, $3 d(0.153 \mathrm{mmol}), \mathrm{Pd}\left(\mathrm{PPh}_{3}\right)_{2} \mathrm{Cl}_{2}(5 \mathrm{~mol} \%$ with respect to $3 \mathrm{~d}), \mathrm{BuOAc}, 100{ }^{\circ} \mathrm{C}$, total volume solvent + amine $=1000 \mu \mathrm{L} .{ }^{b}$ Yields were determined by GC-MS. ${ }^{c}$ TMEDA $=\mathrm{Me}_{2} \mathrm{NCH}_{2} \mathrm{CH}_{2} \mathrm{NMe}_{2} .{ }^{d}$ Reaction time when the maximum yield was achieved.

The use of a large excess of $\mathrm{Et}_{2} \mathrm{NH}$ under the same conditions produced tolane 4 ad in almost quantitative yields after $2 \mathrm{~h}$ (Fig. 2).

To optimize the conditions, we studied the effect of excessive amounts of different amines on the kinetics of the reaction. It was found that other amines were also as effective as $\mathrm{Et}_{2} \mathrm{NH}$ when they were used in high excess. The results are summarized in Table 3.

We have to admit that the mechanistic picture of the Stille reaction is rather complex ${ }^{35}$ and details cannot be specified with confidence, so the role of an amine and its amount still remains unclear and requires further investigation. We suggest that the reaction proceeds by way of formation of alkynylpalladium complexes 6 and 7 according to Scheme 6 .

The effect of different catalysts was studied to determine the best catalytic system. No reaction occurs without a catalyst: thus,
Table 4 Effects of the different catalysts on the yields of $4 \mathrm{ad}^{a}$

\begin{tabular}{|c|c|c|c|c|c|c|}
\hline \multirow[b]{2}{*}{ Amine } & \multicolumn{6}{|c|}{ The yield of $4-\mathrm{NO}_{2} \mathrm{C}_{6} \mathrm{H}_{4} \mathrm{C} \equiv \mathrm{CPh} \operatorname{4ad}^{b}(\%)$} \\
\hline & $\mathrm{PdCl}_{2}$ & $\begin{array}{l}\text { Time }^{c} \\
\text { (h) }\end{array}$ & $\mathrm{Pd}(\mathrm{PhCN})_{2} \mathrm{Cl}_{2}$ & $\begin{array}{l}\text { Time } \\
\text { (h) }\end{array}$ & $\mathrm{Pd}\left(\mathrm{PPh}_{3}\right)_{2} \mathrm{Cl}_{2}$ & $\begin{array}{l}\text { Time }^{c} \\
\text { (h) }\end{array}$ \\
\hline $\mathrm{Et}_{2} \mathrm{NH}$ & 13 & 7 & 7 & 5 & 98 & 2 \\
\hline $\mathrm{Et}_{3} \mathrm{~N}$ & 72 & 3 & 71 & 2 & 89 & 7 \\
\hline $\mathrm{Bu}_{3} \mathrm{~N}$ & 60 & 7 & 50 & 5 & 97 & 3 \\
\hline DABCO & 57 & 2 & 56 & 1 & 68 & 2 \\
\hline
\end{tabular}

${ }^{a}$ The reaction conditions were as follows: 1a $(0.038 \mathrm{mmol}), 3 \mathbf{d}$ (0.153 mmol), Pd catalyst $(5 \mathrm{~mol} \%$ with respect to $3 \mathbf{d})$, amine (0.153 mmol), BuOAc, $100{ }^{\circ} \mathrm{C}$. ${ }^{b}$ Yields were determined by GC-MS. ${ }^{c}$ Reaction time when the maximum yield was achieved.

when $(\mathrm{PhC} \equiv \mathrm{C})_{4} \mathrm{Sn} \mathbf{1 a}$ was added to $4-\mathrm{NO}_{2} \mathrm{C}_{6} \mathrm{H}_{4} \mathrm{I}$ 3d in pure $\mathrm{Et}_{3} \mathrm{~N}$ $\left(80{ }^{\circ} \mathrm{C}, 2 \mathrm{~h}\right)$, no conversion was observed.

However, when a catalytic amount of CuI was added under the same conditions, a trace amount of the coupling product was detected by GC-MS. It is noteworthy that when $(\mathrm{PhC} \equiv \mathrm{C})_{4} \mathrm{Sn} 1 \mathrm{a}$ was treated with a 4 -fold excess of $\mathrm{CuBr}_{2}$ (THF, $0.5 \mathrm{~h}, 25{ }^{\circ} \mathrm{C}$ ), the oxidative Glaser-type coupling product $(\mathrm{Ph}-\mathrm{C} \equiv \mathrm{C}-)_{2}$ 5a was formed in a good yield. The first success came with the use of $\mathrm{Pd}$ catalysts, especially $\mathrm{Pd}\left(\mathrm{PPh}_{3}\right)_{2} \mathrm{Cl}_{2}$. To our surprise, the reaction was completely suppressed by the addition of an excess of phosphine ligand. Thus, no reaction between stannane 1a and 1-iodo-4-nitrobenzene 3d occurred in the presence of $\mathrm{Pd}\left(\mathrm{PPh}_{3}\right)_{2} \mathrm{Cl}_{2}$ and $\mathrm{PPh}_{3}(5 \mathrm{~mol} \%$ and $20 \mathrm{~mol} \%$ with respect to $\mathbf{3 d}$, respectively), while $\mathrm{Pd}\left(\mathrm{PPh}_{3}\right)_{2} \mathrm{Cl}_{2}$ with no $\mathrm{PPh}_{3}$ additive gave the best yields. The results using different Pd catalysts are summarized in Table 4 .

Next, using an optimized protocol (BuOAc or DMF, $100{ }^{\circ} \mathrm{C}$, $5 \mathrm{~mol} \% \mathrm{Pd}\left(\mathrm{PPh}_{3}\right)_{2} \mathrm{Cl}_{2}$, and an excess (4-fold or more with respect to stannane 1) of an amine additive $-\mathrm{Et}_{2} \mathrm{NH}, \mathrm{Pr}_{2} \mathrm{NH}$, DABCO or $\mathrm{Bu}_{3} \mathrm{~N}$ ), we studied the reactivity of different tetraalkynylstannanes $\mathbf{1}$ and aryl halides $\mathbf{3}$. As expected, aryl halides bearing electron-withdrawing groups showed the best reactivity and gave the highest yields of acetylenes 4 . Selected results are summarized in Table 5; the complete set of data is given in ESI, $\dagger$ Table S1.

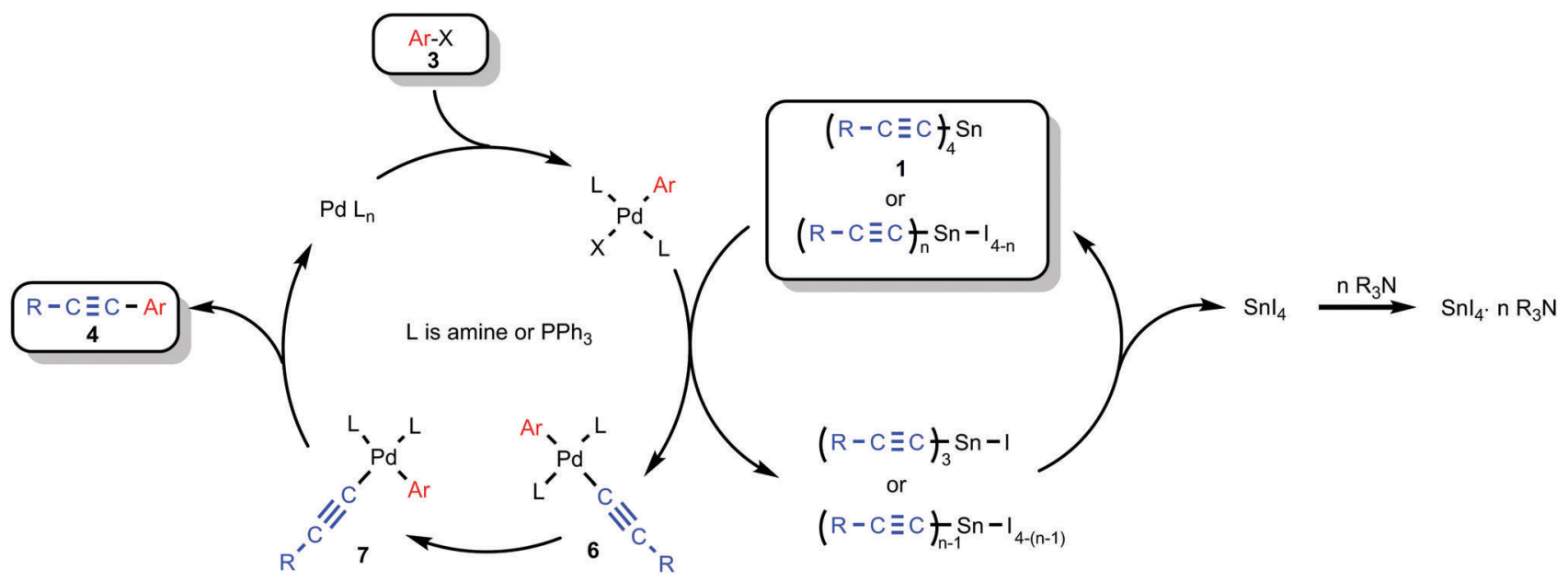

Scheme 6 A possible mechanism for the reaction of tetraalkynylstannanes 1 with aryl halides $\mathbf{3}$. 
Table 5 The reactivity of different aryl halides 3 towards $(\mathrm{PhC} \equiv \mathrm{C})_{4} \mathrm{Sn} \mathbf{1 a}$ under the optimized conditions ${ }^{a}$

\begin{tabular}{|c|c|c|c|c|}
\hline Aryl Halides 3 & Solvent & $\operatorname{Time}^{b}(\mathrm{~h})$ & Amine & Yield of 4 \\
\hline Ph-I 3a & DMF & 2.5 & $\mathrm{Et}_{3} \mathrm{~N}$ & 87 \\
\hline $4-\mathrm{MeC}_{6} \mathrm{H}_{4} \mathrm{I} \mathbf{3 b}$ & DMF & 5 & $\mathrm{Et}_{3} \mathrm{~N}$ & 95 \\
\hline $4-\mathrm{MeC}_{6} \mathrm{H}_{4} \mathrm{I} 3 \mathbf{b}$ & BuOAc & 9 & $\mathrm{Et}_{2} \mathrm{NH}$ & 54 \\
\hline $4-\mathrm{NO}_{2} \mathrm{C}_{6} \mathrm{H}_{4} \mathrm{I} 3 \mathrm{~d}$ & DMF & 2.5 & $\mathrm{Et}_{3} \mathrm{~N}$ & 89 \\
\hline $4-\mathrm{NO}_{2} \mathrm{C}_{6} \mathrm{H}_{4} \mathrm{I} 3 \mathrm{~d}$ & BuOAc & 6 & $\mathrm{Et}_{2} \mathrm{NH}$ & 98 \\
\hline $4-\mathrm{NO}_{2} \mathrm{C}_{6} \mathrm{H}_{4} \mathrm{I} 3 \mathrm{~d}$ & BuOAc & 1 & $\mathrm{Pr}_{2} \mathrm{NH}$ & 99.5 \\
\hline $4-\mathrm{NO}_{2} \mathrm{C}_{6} \mathrm{H}_{4} \mathrm{I} 3 \mathrm{~d}$ & BuOAc & 3 & $\mathrm{Bu}_{3} \mathrm{~N}$ & 97 \\
\hline $4-\mathrm{MeC}_{6} \mathrm{H}_{4} \mathrm{Br} 3 \mathbf{h}$ & BuOAc & 9 & $\mathrm{Et}_{2} \mathrm{NH}$ & 11 \\
\hline $4-\mathrm{MeOC}_{6} \mathrm{H}_{4} \mathrm{Br} 3 \mathbf{i}$ & BuOAc & 5 & $\mathrm{Et}_{2} \mathrm{NH}$ & 7 \\
\hline $4-\mathrm{MeOC}_{6} \mathrm{H}_{4} \mathrm{Br} 3 \mathbf{i}$ & BuOAc & 3 & DABCO & 15 \\
\hline $2-\mathrm{NO}_{2} \mathrm{C}_{6} \mathrm{H}_{4} \mathrm{I} 3 \mathrm{k}$ & BuOAc & 10 & $\mathrm{Et}_{2} \mathrm{NH}$ & 83 \\
\hline $2-\mathrm{IC}_{6} \mathrm{H}_{4} \mathrm{CO}_{2} \mathrm{H} 3 \mathrm{l}$ & BuOAc & 5 & $\mathrm{Et}_{2} \mathrm{NH}$ & 0 \\
\hline $2-\mathrm{IC}_{6} \mathrm{H}_{4} \mathrm{CO}_{2} \mathrm{H} 3 \mathrm{l}$ & $\mathrm{Et}_{3} \mathrm{~N}$ & 4 & $\mathrm{Et}_{3} \mathrm{~N}$ & 63 \\
\hline
\end{tabular}

${ }^{a}$ Yields were determined by GC-MS. Unless otherwise stated, the reaction conditions were as follows: $1 \mathrm{a}(0.038 \mathrm{mmol}), \mathbf{3 d}(0.153 \mathrm{mmol})$, $\mathrm{Pd}\left(\mathrm{PPh}_{3}\right)_{2} \mathrm{Cl}_{2}(5 \mathrm{~mol} \%$ with respect to $3 \mathrm{~d})$, amine $(0.153 \mathrm{mmol})$ and solvent (DMF or BuOAc, $2 \mathrm{~mL}$ ) at $100{ }^{\circ} \mathrm{C} .{ }^{b}$ Reaction time when the maximum yield was achieved.

However, when the reaction was carried out using DMF as a solvent instead of BuOAc, the coupling products with aryl halides 3 bearing electron-donating substituents were obtained

Table 6 The reactivity of different tetraalkynylstannanes 1 towards 4- $\mathrm{NO}_{2} \mathrm{C}_{6} \mathrm{H}_{4} \mathrm{l} 3 \mathrm{~d}$ under the optimized conditions ${ }^{a}$

\begin{tabular}{llll}
\hline Tetraalkynylstannanes 1 & Time $^{b}(\mathrm{~h})$ & Amine & Yields of $\mathbf{4}(\%)$ \\
\hline$(\mathrm{PhC} \equiv \mathrm{C})_{4} \mathrm{Sn} \mathrm{1a}$ & 2 & $\mathrm{Et}_{2} \mathrm{NH}$ & 98 \\
$\left(t-\mathrm{BuOCH} \mathrm{H}_{2} \mathrm{C} \equiv \mathrm{C}\right)_{4} \mathrm{Sn} \mathrm{1e}$ & 1 & $\mathrm{DABCO}$ & 74 \\
$\left(t-\mathrm{BuOCH}_{2} \mathrm{C} \equiv \mathrm{C}\right)_{4} \mathrm{Sn} \mathrm{1e}$ & 2 & $\mathrm{Et}_{2} \mathrm{NH}$ & 33 \\
$\left(n-\mathrm{C}_{8} \mathrm{H}_{18} \mathrm{CH}_{2} \mathrm{C} \equiv \mathrm{C}\right)_{4} \mathrm{Sn} \mathrm{1g}$ & 7 & $\mathrm{Et}_{2} \mathrm{NH}$ & 50 \\
$\left(n-\mathrm{C}_{8} \mathrm{H}_{18} \mathrm{CH}_{2} \mathrm{C} \equiv \mathrm{C}\right)_{4} \mathrm{Sn} \mathrm{1g}$ & 5 & DABCO & 52
\end{tabular}

${ }^{a}$ Yields were determined by GC-MS. The reaction conditions were as follows: 1 (0.038 mmol), 3d $(0.153 \mathrm{mmol}), \mathrm{Pd}\left(\mathrm{PPh}_{3}\right)_{2} \mathrm{Cl}_{2}(5 \mathrm{~mol} \%$ with respect to 3d), amine $(0.153 \mathrm{mmol})$, BuOAc $(2 \mathrm{~mL})$ at $100{ }^{\circ} \mathrm{C} .{ }^{b}$ Reaction time when the maximum yield was achieved. in good yields. The analogs of $(\mathrm{PhC} \equiv \mathrm{C})_{4} \mathrm{Sn}$ 1a, i.e., tetraalkynylstannanes $\mathbf{1 b}-\mathbf{g}$, reacted with $4-\mathrm{NO}_{2} \mathrm{C}_{6} \mathrm{H}_{4} \mathrm{I}$ 3d to form the desired acetylenes $\mathbf{4 b d}-\mathbf{g d}$, but the yields were generally lower than those obtained with 1a. The selected results are presented in Table 6. Finally, the Stille coupling products 4 were obtained in $40-93 \%$ yields in preparative-scale experiments using conditions similar to those of the kinetic runs and the optimization protocols. The results are given in Table 7.

\section{Conclusions}

In conclusion, we have developed an effective synthetic protocol based on the Stille cross coupling reaction of easily available tetraalkynylstannanes with aryl halides. The reported method provides atom-economical access to aryl acetylenes and diaryl acetylenes (tolanes) which are valuable reagents for further transformations. The scope and limitations of the reaction were studied and the conditions were optimized.

\section{Experimental}

\section{Materials and methods}

Solvents and starting reagents were thoroughly dried and purified according to common procedures. ${ }^{36}$ All reactions were carried out and the target compounds were isolated in an argon (99.993\%) atmosphere. ${ }^{1} \mathrm{H},{ }^{13} \mathrm{C}$, and ${ }^{119} \mathrm{Sn}$ NMR spectra were recorded on a JEOL ECA 400 instrument at operating frequencies of $399.78,100.52$ and $149.08 \mathrm{MHz}$ respectively, in $\mathrm{CDCl}_{3}$ (Aldrich) with reference to TMS or to the residual signals of a solvent (with $\mathrm{SnMe}_{4}$ as a standard for ${ }^{119} \mathrm{Sn} \mathrm{NMR}$ ). Chemical shifts are given in ppm; coupling constants are given in Hz. IR spectra were recorded on an InfraLUM FT-02 instrument in the range of $400-4200 \mathrm{~cm}^{-1}$ ( $\mathrm{KBr}$ or $\mathrm{HCCl}_{3}$ solution) and on a Bruker Vertex 70 instrument in ATR (attenuated total reflection) mode.

Table 7 The preparative-scale synthesis of acetylenes 4

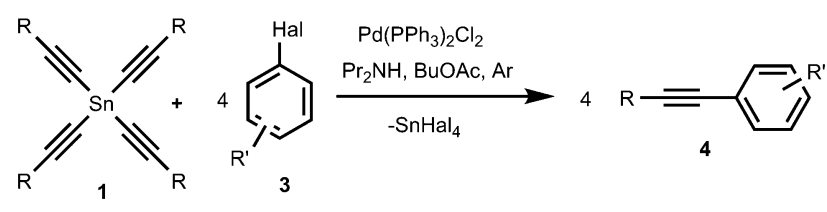

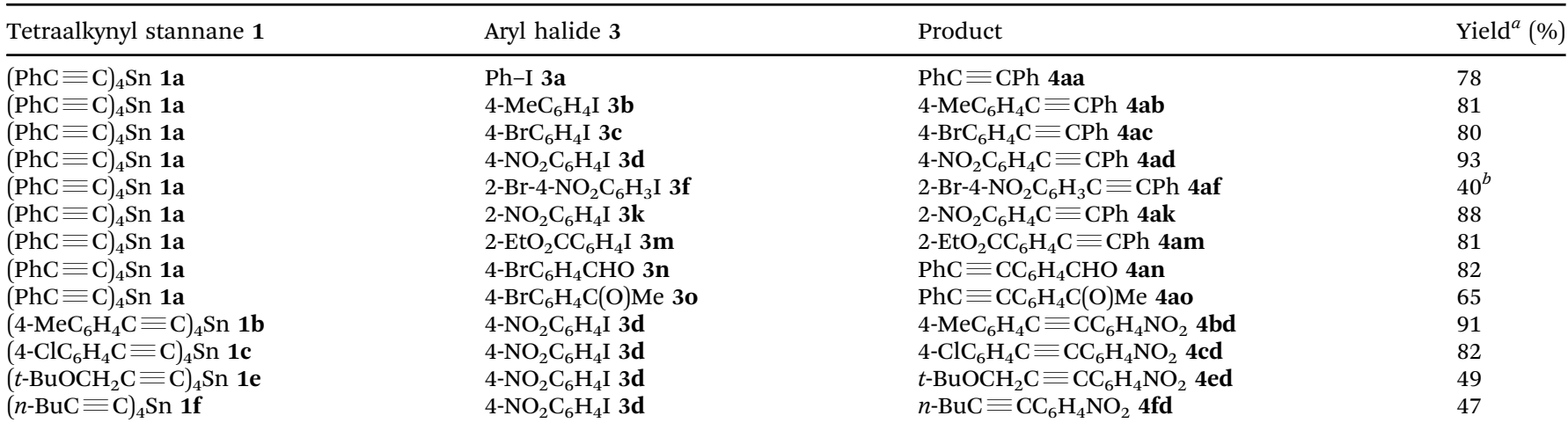

${ }^{a}$ Isolated yields are given. ${ }^{b}$ When 2-Br-4- $\mathrm{NO}_{2} \mathrm{C}_{6} \mathrm{H}_{3} \mathrm{I}$ 3f and $(\mathrm{PhC} \equiv \mathrm{C})_{4} \mathrm{Sn} \mathbf{1 a}$ were added in a $2: 1$ ratio, acetylene 4 af was obtained in $81 \%$ yield. 
Mass spectra (EI, $70 \mathrm{eV}$ ) were obtained on a Shimadzu GCMS-QP 2010 spectrometer. The purity of the compounds was checked by TLC (Sorbfil A plates) with $\mathrm{Et}_{2} \mathrm{O}:$ hexane $(10: 1), \mathrm{MeOH}: \mathrm{HCCl}_{3}$ $(1: 10)$ or $\mathrm{HCCl}_{3}: \mathrm{Me}_{2} \mathrm{CO}(10: 1)$ mixtures as eluents. The spots were visualized with iodine vapors, $\mathrm{KMnO}_{4}-\mathrm{H}_{2} \mathrm{SO}_{4}$ solution or UV-light. The starting tetraalkynylstannanes $\mathbf{1 a}-\mathbf{g}$ were obtained according to the reported methods $;^{20,21}$ the detailed procedures are given in the ESI. $\dagger$

General procedure for the synthesis of 4-nitrotolane (1-nitro-4(phenylethynyl)benzene) (4ad) (the model reaction, Scheme 5, Tables 1, 2 and 4)

A $5 \mathrm{~mL}$ sealable Wheaton vial was charged with $0.00765 \mathrm{mmol}$ of $\mathrm{Pd}$ catalyst $\left(\mathrm{PdCl}_{2}, \mathrm{Pd}\left(\mathrm{PPh}_{3}\right)_{2} \mathrm{Cl}_{2}\right.$, or $\left.\mathrm{Pd}(\mathrm{PhCN})_{2} \mathrm{Cl}_{2}\right)$ and $0.153 \mathrm{mmol}$ of the amine additive $\left(\mathrm{Et}_{2} \mathrm{NH}, \mathrm{Et}_{3} \mathrm{~N}, \mathrm{Bu}_{3} \mathrm{~N}, \mathrm{DABCO}\right.$, morpholine, etc.). Then the vial was flushed with a stream of dry argon, and subsequently a solution of $0.0382 \mathrm{mmol}$ of $(\mathrm{PhC} \equiv \mathrm{C})_{4} \mathrm{Sn} 1 \mathrm{a}$ in a dry solvent $(1 \mathrm{~mL})$ and a solution of $0.153 \mathrm{mmol}$ of $4-\mathrm{NO}_{2} \mathrm{C}_{6} \mathrm{H}_{4} \mathrm{I}$ in a dry solvent $(1 \mathrm{~mL})$ were added through a syringe. The mixture was stirred for the indicated time, and the yield was determined by GC-MS.

Preparative procedure for the synthesis of tolane (diphenyl acetylene) (4aa) from (PhC $\equiv \mathrm{C})_{4} \mathrm{Sn}$ (1a). A dry $25 \mathrm{~mL}$, twonecked, round-bottomed flask equipped with an argon gas inlet tube and a magnetic stirrer was flushed with argon and charged with iodobenzene 3a (212.7 mg, $1.043 \mathrm{mmol}), \mathrm{Pd}\left(\mathrm{PPh}_{3}\right)_{2} \mathrm{Cl}_{2}$ (36.6 mg, $0.052 \mathrm{mmol} ; 5 \mathrm{~mol} \%$ vs. 3a) and $(\mathrm{PhC} \equiv \mathrm{C})_{4} \mathrm{Sn} \mathrm{1a}$ (150 mg, $0.287 \mathrm{mmol}$ ). Then $\operatorname{Pr}_{2} \mathrm{NH}(1.43 \mathrm{~mL}, 10.43 \mathrm{mmol})$ and dry BuOAc $(6 \mathrm{~mL})$ were added, the solution was degassed by freezing in liquid nitrogen and pumping under vacuum several times, and then it was flushed with argon. The reaction mixture was stirred at $100{ }^{\circ} \mathrm{C}$ for $5 \mathrm{~h}$, then allowed to cool and quenched with EtOH $(10 \mathrm{~mL})$. The mixture was treated with $0.5 \mathrm{~g}$ of silica modified with 3-aminopropyltriethoxysilane, the solvent was removed on a rotary evaporator and the traces of BuOAc were removed in vacuo. The resulting mixture was purified by column chromatography over silica gel (2 g) with pure dry PhMe $(50 \mathrm{~mL})$. The eluent was evaporated, the residue was dissolved in $n$-hexane and purified by column chromatography on a mixture of silica gel $(6 \mathrm{~g})$ and silica gel modified with 3-aminopropyltriethoxysilane $\left(1 \mathrm{~g}, 1.14 \mathrm{mmol} \mathrm{g}{ }^{-1}\right.$ of $\mathrm{NH}_{2}$ groups; the use of the modified silica gel allowed us to remove easily the by-product $\mathrm{SnI}_{4}$, which appears to be hard to separate when a non-modified silica gel is used as sorbent). Hexane was used as the eluent. Column fractions were analyzed by GC-MS. The eluent was evaporated to give $152.3 \mathrm{mg}$ of tolane $4 \mathbf{a a}$ as a colorless crystalline solid (78\%, purity by GCMS - 95.3\%).

${ }^{1} \mathrm{H}$ NMR (400 MHz, $\left.\mathrm{CDCl}_{3}\right) \delta 7.33-7.73(\mathrm{~m}, 6 \mathrm{H}, \mathrm{Ph}), 7.52-$ $7.54(\mathrm{~m}, 4 \mathrm{H}, \mathrm{Ph}) ;{ }^{13} \mathrm{C} \mathrm{NMR}\left(100 \mathrm{MHz}, \mathrm{CDCl}_{3}\right) \delta 89.4,123.3$, 128.2, 128.3, 131.6. IR (KBr, cm $\left.{ }^{-1}\right) \nu_{\max } 3063,2928$ (C-H, C-C), $1599(\mathrm{C}=\mathrm{C}) . \mathrm{MS}(\mathrm{m} / \mathrm{z}, \mathrm{EI}, 70 \mathrm{eV}) 178\left(\left[\mathrm{M}^{+}\right], 100\right), 152\left(\left[\mathrm{M}-\mathrm{C}_{2} \mathrm{H}_{2}\right]^{+}\right.$, 17.6), 77 ([Ph $\left.]^{+}, 3.3\right)$.

4-Methyltolane (1-methyl-4-(phenylethynyl)benzene) (4ab). A dry $25 \mathrm{~mL}$, two-necked, round-bottomed flask equipped with an argon gas inlet tube and a magnetic stirrer was flushed with argon and charged with 4-iodotoluene (3b) (227.4 mg, $1.043 \mathrm{mmol}$ ),
$\mathrm{Pd}\left(\mathrm{PPh}_{3}\right)_{2} \mathrm{Cl}_{2} \quad(36.6 \mathrm{mg}, \quad 0.052 \mathrm{mmol} ; 5 \mathrm{~mol} \%$ vs. $3 \mathbf{b})$ and $(\mathrm{PhC} \equiv \mathrm{C})_{4} \mathrm{Sn} 1 \mathrm{a}(150 \mathrm{mg}, 0.287 \mathrm{mmol})$. Then $\mathrm{Pr}_{2} \mathrm{NH}(1.43 \mathrm{~mL}$, $10.43 \mathrm{mmol})$ and dry BuOAc $(6 \mathrm{~mL})$ were added, the solution was degassed by freezing in liquid nitrogen and pumping under vacuum several times, and then it was flushed with argon. The reaction mixture was stirred at $100{ }^{\circ} \mathrm{C}$ for $5 \mathrm{~h}$, then allowed to cool and quenched with EtOH $(10 \mathrm{~mL})$. The mixture was treated with $0.5 \mathrm{~g}$ of silica modified with 3-aminopropyltriethoxysilane, the solvent was removed on a rotary evaporator and the traces of BuOAc were removed in vacuo. The resulting mixture was purified by column chromatography on a mixture of silica gel (6 g) and silica gel modified with 3-aminopropyltriethoxysilane ( $1 \mathrm{~g}, 1.14 \mathrm{mmol} \mathrm{g}^{-1}$ of $\mathrm{NH}_{2}$ groups). Hexane was used as the eluent. The yield of $\mathbf{4 a b}$ was $81 \%(161.8 \mathrm{mg})$, white crystalline solid. ${ }^{1} \mathrm{H}$ NMR (400 MHz, $\left.\mathrm{CDCl}_{3}\right) \delta 2.35$ (s, 3H, Me), 7.114 (d, ${ }^{3} J=$ 8.0 Hz, 2H, Ar), 7.29-7.35 (m, 3H, Ph), 7.42 (d, ${ }^{3} \mathrm{~J}=8.0 \mathrm{~Hz}, 2 \mathrm{H}, \mathrm{Ar}$ ), 7.50-7.53 (m, 2H, Ph); ${ }^{13} \mathrm{C}$ NMR (100 MHz, $\left.\mathrm{CDCl}_{3}\right) \delta 21.5,88.7$, 89.6, 120.2, 123.5, 128.1, 128.3, 129.1, 131.6, 132.5, 138.4. IR $\left(\mathrm{KBr}, \mathrm{cm}^{-1}\right) \nu_{\max } 2920.6,2853.1(\mathrm{C}-\mathrm{H}, \mathrm{C}-\mathrm{C}), 2214.6(\mathrm{C} \equiv \mathrm{C})$, $1595.3(\mathrm{C}=\mathrm{C})$. MS (m/z, EI, $70 \mathrm{eV}) 192\left(\left[\mathrm{M}^{+}\right], 100\right), 115$ $\left([\mathrm{M}-\mathrm{Ph}]^{+}, 8.3\right), 77\left([\mathrm{Ph}]^{+}, 2.6\right)$.

4-Bromotolane (1-bromo-4-(phenylethynyl)benzene) (4ac). 4-Bromotolane (4ac) was prepared using a similar procedure to that for $4 \mathbf{a b}$, using 1-bromo-4-iodobenzene (3c) $(295 \mathrm{mg}$, $1.043 \mathrm{mmol}$ ) instead of 4 -iodotoluene (3b). The yield was $80 \%$ (214.4 mg), white crystalline solid. ${ }^{1} \mathrm{H}$ NMR (400 $\mathrm{MHz}, \mathrm{CDCl}_{3}$ ) $\delta 7.32-7.35$ (m, 3H, Ar), 7.38 (d, $\left.{ }^{3} J=8.7 \mathrm{~Hz}, 2 \mathrm{H}, \mathrm{Ar}\right), 7.47$ (d, ${ }^{3} J=$ $8.7 \mathrm{~Hz}, 2 \mathrm{H}, \mathrm{Ar}), 7.50-7.53(\mathrm{~m}, 2 \mathrm{H}, \mathrm{Ar}) ;{ }^{13} \mathrm{C}$ NMR $(100 \mathrm{MHz}$, $\left.\mathrm{CDCl}_{3}\right) \delta 88.3,90.5,122.3,122.5,122.9,128.4,128.5,131.60$, 131.62, 133.0. IR (KBr, cm $\left.{ }^{-1}\right) \nu_{\max } 3049.8,2924.4,2855$ (C-H, C-C), $2214.6(\mathrm{C} \equiv \mathrm{C}), 1599.2(\mathrm{C}=\mathrm{C}) . \mathrm{MS}(\mathrm{m} / z$, EI, $70 \mathrm{eV}) 258\left(\left[\mathrm{M}^{+}{ }^{81} \mathrm{Br}\right]\right.$, 97.2), 256 ([$\left.\left[\mathrm{M}^{+}{ }^{79} \mathrm{Br}\right], 100\right), 177$ ([M - Br $\left.]^{+}, 13.6\right), 77$ ([Ph $\left.]^{+}, 6.8\right)$.

4-Nitrotolane (1-nitro-4-(phenylethynyl)benzene) (4ad). 4-Nitrotolane was prepared using a similar procedure to that for $\mathbf{4 a b}$, using 1-iodo-4-nitrobenzene (3d) (259.7 mg, $1.043 \mathrm{mmol}$ ) instead of 4 -iodotoluene (3b). The reaction time was $1 \mathrm{~h} 40 \mathrm{~min}$. The yield was $93 \%$ (216.5 mg), light yellow crystals. ${ }^{1} \mathrm{H}$ NMR $(400 \mathrm{MHz}$, $\left.\mathrm{CDCl}_{3}\right) \delta 7.38-7.39(\mathrm{~m}, 3 \mathrm{H}, \mathrm{Ph}), 7.54-7.56$ (m, 2H, Ph), 7.65 (d, ${ }^{3} \mathrm{~J}=$ $8.7 \mathrm{~Hz}, 2 \mathrm{H}, \mathrm{Ar}), 8.20$ (d, $\left.{ }^{3} \mathrm{~J}=8.7 \mathrm{~Hz}, 2 \mathrm{H}, \mathrm{Ar}\right) ;{ }^{13} \mathrm{C} \mathrm{NMR}(100 \mathrm{MHz}$, $\left.\mathrm{CDCl}_{3}\right) \delta 87.6,94.7,122.1,123.6,128.6,129.3,130.3,131.9,132.3$, 147.0. IR (KBr, cm ${ }^{-1}$ ) $\nu_{\max } 2922.5,2851.1$ (C-H, C-C), 2216.5 $(\mathrm{C} \equiv \mathrm{C}), 1591.5(\mathrm{C}=\mathrm{C}), 1346.5$ (symm NO$)_{2}$. MS $(\mathrm{m} / \mathrm{z}, \mathrm{EI}, 70 \mathrm{eV})$ $223\left(\left[\mathrm{M}^{+}\right], 100\right), 177\left(\left[\mathrm{M}-\mathrm{NO}_{2}\right]^{+}, 21.1\right), 77\left([\mathrm{Ph}]^{+}, 8.8\right)$.

2-Bromo-4-nitro-1-(phenylethynyl)benzene (4af). A vial was charged with 2-bromo-1-iodo-4-nitrobenzene (3f) $(102.5 \mathrm{mg}$, $0.313 \mathrm{mmol}), \mathrm{Pd}\left(\mathrm{PPh}_{3}\right)_{2} \mathrm{Cl}_{2}$ (11.0 mg, $0.016 \mathrm{mmol} ; 5 \mathrm{~mol} \%$ vs. 3f) and $(\mathrm{PhC} \equiv \mathrm{C})_{4} \mathrm{Sn} 1 \mathrm{a}(90 \mathrm{mg}, 0.172 \mathrm{mmol})$. Then $\mathrm{Pr}_{2} \mathrm{NH}(0.43 \mathrm{~mL}$, $3.13 \mathrm{mmol})$ and dry BuOAc $(1.8 \mathrm{~mL})$ were added, the solution was degassed by freezing in liquid nitrogen and pumping under vacuum several times, and then the vial was flushed with argon. The reaction mixture was stirred at $100{ }^{\circ} \mathrm{C}$ for $4.5 \mathrm{~h}$, then allowed to cool and quenched with EtOH $(2 \mathrm{~mL})$. The mixture was treated with $0.2 \mathrm{~g}$ of silica gel modified with 3-aminopropyltriethoxysilane, the solvent was removed on a rotary evaporator and the traces of BuOAc were removed in vacuo. The resulting mixture was purified by column chromatography on a mixture of silica gel $(6 \mathrm{~g})$ and 
silica gel modified with 3-aminopropyltriethoxysilane (1 g, $1.14 \mathrm{mmol} \mathrm{g}^{-1}$ of $\mathrm{NH}_{2}$ groups), eluted with hexane, then hexane: PhMe $4: 1$. Column fractions were analyzed by GCMS. The eluent was evaporated to give $76 \mathrm{mg}$ (81\%) of acetylene 4 af as a yellow crystalline solid. In addition, the sample could be recrystallized from $n$-heptane. ${ }^{1} \mathrm{H}$ NMR $\left(400 \mathrm{MHz}, \mathrm{CDCl}_{3}\right) \delta$ 7.38-7.42 (m, 3H, Ph), 7.59-7.61 (m, 2H, Ph), $7.68\left(\mathrm{~d},{ }^{3} J=8.2 \mathrm{~Hz}\right.$, $1 \mathrm{H}, \mathrm{H}-6 \mathrm{Ar}$ ), 8.20 (dd, ${ }^{3} J=8.2 \mathrm{~Hz},{ }^{4} J=2.3 \mathrm{~Hz}, 1 \mathrm{H}, \mathrm{H}-5 \mathrm{Ar}$ ), 8.48 $\left(\mathrm{d},{ }^{4} \mathrm{~J}=2.3 \mathrm{~Hz}, 1 \mathrm{H}, \mathrm{H}-3 \mathrm{Ar}\right) ;{ }^{13} \mathrm{C} \mathrm{NMR}\left(100 \mathrm{MHz}, \mathrm{CDCl}_{3}\right) \delta 86.8$, 99.5, 121.8, 122.1, 125.9, 127.6, 128.6, 129.7, 132.0, 132.1, 133.3, 146.9. IR (KBr, cm $\left.{ }^{-1}\right) \nu_{\max } 3094.2,3074.9$ (C-H, C-C), 2218.4 $(\mathrm{C} \equiv \mathrm{C}), 1583.8(\mathrm{C}=\mathrm{C}), 1340.7\left(\mathrm{symm} \mathrm{NO}_{2}\right) . \mathrm{MS}(\mathrm{m} / \mathrm{z}, \mathrm{EI}, 70 \mathrm{eV})$ $303\left(\left[\mathrm{M}^{+}{ }^{81} \mathrm{Br}\right], 59.4\right), 301\left(\left[\mathrm{M}^{+}{ }^{79} \mathrm{Br}\right], 60.2\right), 257\left(\left[\left(\mathrm{M}-\mathrm{NO}_{2}\right)^{+}\right.\right.$, $\left.\left.{ }^{81} \mathrm{Br}\right], 0.8\right), 255\left(\left[\left(\mathrm{M}-\mathrm{NO}_{2}\right)^{+},{ }^{79} \mathrm{Br}\right], 0.9\right), 176\left(\left(\left[\mathrm{M}-\mathrm{NO}_{2}-\mathrm{Br}\right]\right)^{+}\right.$, 100), $77\left([\mathrm{Ph}]^{+}, 1.6\right)$.

2-Nitrotolane (2-nitro-4-(phenylethynyl)benzene) (4ak). 2-Nitrotolane was prepared using a similar procedure to that for $\mathbf{4 a b}$, using 1-iodo-2-nitrobenzene (3k) $(259.7 \mathrm{mg}, 1.043 \mathrm{mmol})$ instead of 4-iodotoluene (3b). The reaction time was $3.5 \mathrm{~h}$. The yield was $88 \%$ (205 mg), red oil. ${ }^{1} \mathrm{H}$ NMR (400 $\left.\mathrm{MHz}, \mathrm{CDCl}_{3}\right) \delta$ 7.35-7.38 (m, 3H, Ph), 7.42-7.46 (m, 1H, Ar), 7.56-7.60 (m, 3H, Ar), 7.70 (d, ${ }^{3} J=7.8 \mathrm{~Hz}, 1 \mathrm{H}, \mathrm{Ar}$ ), 8.06 (d, ${ }^{3} J=8.3 \mathrm{~Hz}, 1 \mathrm{H}, \mathrm{Ar}$ ); ${ }^{13} \mathrm{C} \mathrm{NMR}$ $\left(100 \mathrm{MHz}, \mathrm{CDCl}_{3}\right) \delta 84.8,97.1,118.7,122.4,124.7,128.45,128.54$, 129.2 132.0, 132.8, 134.6, 149.6. IR (neat, $\mathrm{cm}^{-1}$ ) $\nu_{\max } 3059.9$ (C-C, $\mathrm{C}-\mathrm{H}), 2219.0(\mathrm{C} \equiv \mathrm{C}), 1339.5$ (symm NO $\mathrm{N}_{2}$. MS (m/z, EI, $\left.70 \mathrm{eV}\right) 223$ $\left(\left[\mathrm{M}^{+}\right], 5.2\right), 177\left(\left[\mathrm{M}-\mathrm{NO}_{2}\right]^{+}, 3.8\right), 77\left([\mathrm{Ph}]^{+}, 89.0\right)$.

Ethyl 2-(phenylethynyl)benzoate (4am). A dry $25 \mathrm{~mL}$, twonecked, round-bottomed flask equipped with an argon gas inlet tube and a magnetic stirrer was flushed with argon and charged with 2- $\mathrm{IC}_{6} \mathrm{H}_{4} \mathrm{C}(\mathrm{O}) \mathrm{OEt}(3 \mathrm{~m})$ (287.9 mg, $\left.1.043 \mathrm{mmol}\right), \mathrm{Pd}\left(\mathrm{PPh}_{3}\right)_{2} \mathrm{Cl}_{2}$ (36.6 mg, $0.052 \mathrm{mmol} ; 5 \mathrm{~mol} \%$ vs. $3 \mathrm{~m})$ and $(\mathrm{PhC} \equiv \mathrm{C})_{4} \mathrm{Sn} \mathbf{1 a}$ (150 mg, $0.287 \mathrm{mmol}$ ). Then TMEDA (1.56 mL, $10.43 \mathrm{mmol}$ ) and dry BuOAc $(6 \mathrm{~mL})$ were added, the solution was degassed by freezing in liquid nitrogen and pumping under vacuum several times, and then it was flushed with argon. The reaction mixture was stirred at $100{ }^{\circ} \mathrm{C}$ for $5 \mathrm{~h}$, then allowed to cool and quenched with EtOH $(10 \mathrm{~mL})$. The mixture was treated with $0.5 \mathrm{~g}$ of silica gel modified with 3-aminopropyltriethoxysilane, the solvent was removed on a rotary evaporator and the traces of BuOAc were removed in vacuo. The resulting mixture was purified by column chromatography on a mixture of silica gel $(6 \mathrm{~g})$ and silica gel modified with 3-aminopropyltriethoxysilane $\left(1 \mathrm{~g}, 1.14 \mathrm{mmol} \mathrm{g}^{-1}\right.$ of $\mathrm{NH}_{2}$ groups), eluted with hexane, then with hexane : PhMe $4: 1$ (after diphenyldiacetylene 5a was eluted). Column fractions were analyzed by GCMS. The eluent was evaporated to give $243 \mathrm{mg}$ (purity by GCMS - 87.3\%) of benzoate 4am as a yellow solid. The product was further purified with flash chromatography ( $2 \mathrm{~g}$ of silica gel, hexane). Yield $81 \% .{ }^{1} \mathrm{H}$ NMR (400 $\mathrm{MHz}, \mathrm{CDCl}_{3}$ ) $\delta 1.40\left(\mathrm{t},{ }^{3} \mathrm{~J}=7.3 \mathrm{~Hz}, 3 \mathrm{H}, \mathrm{OCH}_{2} \mathrm{CH}_{3}\right), 4.42\left(\mathrm{q},{ }^{3} J=7.3 \mathrm{~Hz}, 2 \mathrm{H}\right.$, $\mathrm{OCH}_{2} \mathrm{CH}_{3}$ ), 7.34-7.39 (m, 4H, Ar), 7.46-7.50 (m, 1H, Ar), 7.56$7.58(\mathrm{~m}, 2 \mathrm{H}, \mathrm{Ar}), 7.64\left(\mathrm{~d},{ }^{3} J=8.2 \mathrm{~Hz}, 1 \mathrm{H}, \mathrm{Ar}\right), 7.97\left(\mathrm{dd},{ }^{3} J=\right.$ $\left.7.8 \mathrm{~Hz},{ }^{4} J=0.9 \mathrm{~Hz}, 1 \mathrm{H}, \mathrm{Ar}\right) ;{ }^{13} \mathrm{C} \mathrm{NMR}\left(100 \mathrm{MHz}, \mathrm{CDCl}_{3}\right) \delta 14.4$, 61.2, 88.3, 94.2, 123.4, 123.6, 127.9, 128.4, 128.5, 130.4, 131.5, 131.7, 132.3, 134.0, 166.4. IR (KBr, cm $\left.{ }^{-1}\right) \nu_{\max } 3061.4,2982.3$ (C-H, C-C), $2218.4(\mathrm{C} \equiv \mathrm{C}), 1726.5(\mathrm{C}=\mathrm{O}) . \mathrm{MS}(\mathrm{m} / \mathrm{z}, \mathrm{EI}, 70 \mathrm{eV})$ 250 ([ $\left.\left.\mathrm{M}^{+}\right], 94.4\right), 235$ ([M - Me $\left.]^{+}, 3.0\right), 222$ ([M - CO $\left.]^{+}, 100\right), 221$
([M - Et $\left.]^{+}, 29.7\right), 205\left([\mathrm{M}-\mathrm{EtO}]^{+}, 36.0\right), 177$ ([M - COOEt $\left.]^{+}, 22.1\right)$, $77\left([\mathrm{Ph}]^{+}, 13.9\right)$.

4-(Phenylethynyl)benzaldehyde (4an). Aldehyde 4an was prepared using a similar procedure to that for benzoate $4 \mathbf{a m}$, using 4- $\mathrm{BrC}_{6} \mathrm{H}_{4} \mathrm{CHO}$ (3n) (193 mg, $1.043 \mathrm{mmol}$ ), $\mathrm{Pd}\left(\mathrm{PPh}_{3}\right)_{2} \mathrm{Cl}_{2}$ (36.6 mg, $0.052 \mathrm{mmol} ; 5$ mol\% vs. 3n), $(\mathrm{PhC} \equiv \mathrm{C})_{4} \mathrm{Sn} 1 \mathrm{a}$ (150 mg, $0.287 \mathrm{mmol})$, TMEDA (1.56 mL, $10.43 \mathrm{mmol}$ ) and dry BuOAc $(6 \mathrm{~mL})$. The reaction time was $3 \mathrm{~h}$. The yield of crude aldehyde 4an was $176 \mathrm{mg}$. For further purification, the sample was recrystallized from $n$-heptane. Yield $82 \%$, beige crystalline solid. ${ }^{1} \mathrm{H}$ NMR (400 MHz, $\left.\mathrm{CDCl}_{3}\right) \delta 7.36-7.38$ (m, 3H, Ph), 7.54$7.57(\mathrm{~m}, 2 \mathrm{H}, \mathrm{Ph}), 7.67\left(\mathrm{~d},{ }^{3} J=8.2 \mathrm{~Hz}, 2 \mathrm{H}, \mathrm{Ar}\right), 7.85\left(\mathrm{~d},{ }^{3} J=8.2 \mathrm{~Hz}\right.$, $2 \mathrm{H}, \mathrm{Ar}), 10.00$ (s, $1 \mathrm{H}, \mathrm{CHO}) ;{ }^{13} \mathrm{C} \mathrm{NMR}\left(100 \mathrm{MHz}, \mathrm{CDCl}_{3}\right) \delta 88.5$, 93.5, 122.5, 128.5, 129.0, 129.58, 129.60, 131.8, 132.1, 135.4, 191.4. IR (KBr, $\mathrm{cm}^{-1}$ ) $\nu_{\max } 3049.3,2845.8$ (C-C, C-H), 2216.1 $(\mathrm{C} \equiv \mathrm{C}), 1697.3(\mathrm{C}=\mathrm{O}), 1599.9(\mathrm{C}=\mathrm{C}) ; \mathrm{MS}(\mathrm{m} / \mathrm{z}, \mathrm{EI}, 70 \mathrm{eV})$ $206\left(\left[\mathrm{M}^{+}\right], 100\right), 205\left([\mathrm{M}-\mathrm{H}]^{+}, 71.4\right), 178\left([\mathrm{M}-\mathrm{CO}]^{+}, 13.3\right)$, $77\left([\mathrm{Ph}]^{+}, 5.9\right)$.

1-[4-(Phenylethynyl)phenyl]ethanone (4ao). Ketone 4ao was prepared using a similar procedure to that for benzoate 4am, using 4- $\mathrm{BrC}_{6} \mathrm{H}_{4} \mathrm{C}(\mathrm{O}) \mathrm{CH}_{3}$ (3o) (151.4 mg, $0.761 \mathrm{mmol}$ ), $\mathrm{Pd}\left(\mathrm{PPh}_{3}\right)_{2} \mathrm{Cl}_{2} \quad(26.7 \mathrm{mg}, \quad 0.038 \mathrm{mmol} ; 5 \mathrm{~mol} \%$ vs. 30 ), $(\mathrm{PhC} \equiv \mathrm{C})_{4} \mathrm{Sn} 1 \mathrm{a}(109.4 \mathrm{mg}, 0.209 \mathrm{mmol})$, TMEDA $(0.57 \mathrm{~mL}$, $3.8 \mathrm{mmol})$ and dry BuOAc $(4.5 \mathrm{~mL})$. The product was purified by column chromatography on a silica gel $(7 \mathrm{~g})$, eluted with hexane, then hexane:PhMe 4:1 (after diphenyldiacetylene 5a was eluted). The yield of crude ketone 4 ao was $129.3 \mathrm{mg}$ (purity by GCMS - 84\%). For further purification, the sample was recrystallized from $n$-heptane. Yield $65 \%$, white crystalline solid. ${ }^{1} \mathrm{H}$ NMR (400 MHz, $\left.\mathrm{CDCl}_{3}\right) \delta 2.61$ (s, 3H, $\mathrm{COCH}_{3}$ ), 7.367.37 (m, 3H, Ph), 7.53-7.56 (m, 2H, Ph), 7.61 (d, ${ }^{3} J=8.5 \mathrm{~Hz}, 2 \mathrm{H}$, Ar), $7.93\left(\mathrm{~d},{ }^{3} J=8.5 \mathrm{~Hz}, 2 \mathrm{H}, \mathrm{Ar}\right) ;{ }^{13} \mathrm{C} \mathrm{NMR}\left(100 \mathrm{MHz}, \mathrm{CDCl}_{3}\right) \delta$ 26.6, 88.6, 92.7, 122.7, 128.2, 128.3, 128.5, 128.8, 131.7, 131.8, 136.2, 197.3. IR $\left(\mathrm{KBr}, \mathrm{cm}^{-1}\right) \nu_{\max } 3061.4,2997.7$ (C-H, C-C), $2218.4(\mathrm{C} \equiv \mathrm{C}), 1680.2(\mathrm{C}=\mathrm{O}), 1603.0(\mathrm{C}=\mathrm{C}) . \mathrm{MS}(\mathrm{m} / \mathrm{z}, \mathrm{EI}$, $70 \mathrm{eV}) 220\left(\left[\mathrm{M}^{+}\right], 72.5\right), 205\left(\left[\mathrm{M}-\mathrm{CH}_{3}\right]^{+}, 100\right), 177\left(\left[\mathrm{M}-\mathrm{COCH}_{3}\right]^{+}\right.$, 27.8), $77\left([\mathrm{Ph}]^{+}, 6.4\right)$.

1-Methyl-4-[(4-nitrophenyl)ethynyl]benzene (4bd). Acetylene 4bd was prepared using a similar procedure to that for $\mathbf{4 a b}$, using 1-iodo-4-nitrobenzene (3d) (178.3 mg, $0.716 \mathrm{mmol})$, $\mathrm{Pd}\left(\mathrm{PPh}_{3}\right)_{2} \mathrm{Cl}_{2} \quad(25.1 \mathrm{mg}, \quad 0.036 \mathrm{mmol} ; 5 \mathrm{~mol} \%$ vs. $3 \mathrm{~d})$, $\left(4-\mathrm{MeC}_{6} \mathrm{H}_{4} \mathrm{C} \equiv \mathrm{C}\right)_{4} \mathrm{Sn} \quad$ 1b $(114.1 \mathrm{mg}, \quad 0.197 \mathrm{mmol}), \operatorname{Pr}_{2} \mathrm{NH}$ $(0.98 \mathrm{~mL}, 7.16 \mathrm{mmol})$ and BuOAc $(4.5 \mathrm{~mL})$. The reaction time was $3.5 \mathrm{~h}$. The resulting crude product was purified by column chromatography on a mixture of silica gel $(6 \mathrm{~g})$ and silica gel modified with 3-aminopropyltriethoxysilane $\left(1 \mathrm{~g}, 1.14 \mathrm{mmol} \mathrm{g}^{-1}\right.$ of $\mathrm{NH}_{2}$ groups), and subsequently eluted with hexane, hexane : EtOAc 9:1, hexane : EtOAc $4: 1$ and pure toluene. Recrystallization from toluene yielded $108.6 \mathrm{mg}$ (63.9\%) of acetylene $4 \mathbf{b d}$ as a white crystalline solid. Another crop of product $(49.1 \mathrm{mg}$, purity by GC-MS - 95\%) was obtained from the mother liquor. The total yield of tolane 4 bd was $155.2 \mathrm{mg}$ (91\%). ${ }^{1} \mathrm{H}$ NMR $\left(400 \mathrm{MHz}, \mathrm{CDCl}_{3}\right) \delta 2.38\left(\mathrm{~s}, 3 \mathrm{H}, \mathrm{CH}_{3}\right), 7.18\left(\mathrm{~d},{ }^{3} J=7.8 \mathrm{~Hz}, 2 \mathrm{H}\right.$, $4-\mathrm{MeC}_{6} \mathrm{H}_{4}$ ), $7.44\left(\mathrm{~d},{ }^{3} J=7.8 \mathrm{~Hz}, 2 \mathrm{H}, 4-\mathrm{MeC}_{6} \mathrm{H}_{4}\right), 7.63\left(\mathrm{~d},{ }^{3} J=\right.$ $\left.9.2 \mathrm{~Hz}, 2 \mathrm{H}, 4-\mathrm{NO}_{2} \mathrm{C}_{6} \mathrm{H}_{4}\right), 8.19\left(\mathrm{~d},{ }^{3} \mathrm{~J}=9.2 \mathrm{~Hz}, 2 \mathrm{H}, 4-\mathrm{NO}_{2} \mathrm{C}_{6} \mathrm{H}_{4}\right)$; ${ }^{13} \mathrm{C}$ NMR $\left(100 \mathrm{MHz}, \mathrm{CDCl}_{3}\right) \delta$ 21.6, 87.1, 95.1, 119.1, 123.6, 
129.3, 130.5, 131.8, 132.2, 139.7, 146.9. IR $\left(\mathrm{KBr}, \mathrm{cm}^{-1}\right) \nu_{\max }$ 2922.5, 2847.3 (C-H, C-C), $2212.6(\mathrm{C} \equiv \mathrm{C}), 1589.5(\mathrm{C}=\mathrm{C})$, 1342.6 (symm NO $\mathrm{NO}_{2}$ ). MS (m/z, EI, $\left.70 \mathrm{eV}\right) 237$ ([ $\left.\left.\mathrm{M}^{+}\right], 100\right), 191$ $\left(\left[\mathrm{M}-\mathrm{NO}_{2}\right]^{+}, 13.6\right), 176\left(\left[\mathrm{M}-\mathrm{Me}-\mathrm{NO}_{2}\right]^{+}, 17.1\right)$.

1-Chloro-4-[(4-nitrophenyl)ethynyl]benzene (4cd). Acetylene 4cd was prepared using a similar procedure to that for $\mathbf{4 a b}$, using 1-iodo-4-nitrobenzene (3d) (249 mg, $1.00 \mathrm{mmol}), \mathrm{Pd}\left(\mathrm{PPh}_{3}\right)_{2} \mathrm{Cl}_{2}$ (35.1 mg, $0.05 \mathrm{mmol} ; 5 \mathrm{~mol} \%$ vs. 3d), $\left(4-\mathrm{ClC}_{6} \mathrm{H}_{4} \mathrm{C} \equiv \mathrm{C}\right)_{4} \mathrm{Sn} \mathrm{1c}$ (181.7 mg, $0.275 \mathrm{mmol}), \mathrm{Pr}_{2} \mathrm{NH}(1.37 \mathrm{~mL}, 10.0 \mathrm{mmol}$ ) and BuOAc (6 mL). The reaction time was $2.5 \mathrm{~h}$. The resulting crude product was purified by column chromatography on a mixture of silica gel (6 g) and silica gel modified with 3-aminopropyltriethoxysilane ( $1 \mathrm{~g}, 1.14 \mathrm{mmol} \mathrm{g}{ }^{-1}$ of $\mathrm{NH}_{2}$ groups), and subsequently eluted with hexane, hexane: $\operatorname{HCCl}_{3}$ 9:1, hexane: $\mathrm{HCCl}_{3} \quad 3: 2$ and hexane: $\mathrm{HCCl}_{3}$ 1:1. Recrystallization from toluene yielded $160.9 \mathrm{mg}$ (62\%) of acetylene $4 \mathbf{c d}$ as a white crystalline solid. Another crop of product $(49.8 \mathrm{mg}$ ) was isolated from the mother liquor. The total yield was $210.7 \mathrm{mg}$ (82\%). ${ }^{1} \mathrm{H}$ NMR (400 MHz, $\left.\mathrm{CDCl}_{3}\right) \delta 7.36\left(\mathrm{~d},{ }^{3} J=8.2 \mathrm{~Hz}, 2 \mathrm{H}, \mathrm{Ar}\right), 7.49$ (d, $\left.{ }^{3} J=8.2 \mathrm{~Hz}, 2 \mathrm{H}, \mathrm{Ar}\right), 7.65$ (d, $\left.{ }^{3} J=8.7 \mathrm{~Hz}, 2 \mathrm{H}, \mathrm{Ar}\right), 8.22$ (d, ${ }^{3} J=$ 8.7 Hz, 2H, Ar); ${ }^{13} \mathrm{C}$ NMR (100 MHz, $\left.\mathrm{CDCl}_{3}\right) \delta 88.4,93.4,120.6$, 123.7, 129.0, 129.9, 132.3, 133.1, 135.5, 147.2. IR $\left(\mathrm{KBr}, \mathrm{cm}^{-1}\right) \nu_{\max }$ 3092.3, 2926.4, 2851.1 (C-H, C-C), 2210.7 (C $\equiv \mathrm{C}), 1587.6$ $(\mathrm{C}=\mathrm{C}), 1346.5$ (symm NO $\left.\mathrm{NO}_{2}\right) . \mathrm{MS}(\mathrm{m} / \mathrm{z}, \mathrm{EI}, 70 \mathrm{eV}) 259\left(\left[\mathrm{M}^{+}\right]{ }^{37} \mathrm{Cl}\right.$, 32.7), $257\left(\left[\mathrm{M}^{+}\right]{ }^{35} \mathrm{Cl}, 100\right), 213\left(\left[\mathrm{M}-\mathrm{NO}_{2}\right]{ }^{+}{ }^{37} \mathrm{Cl}, 2.8\right), 211$ $\left(\left[\mathrm{M}-\mathrm{NO}_{2}\right]^{+35} \mathrm{Cl}, 9.5\right), 176\left(\left[\mathrm{M}-\mathrm{Cl}-\mathrm{NO}_{2}\right]^{+}, 82.7\right)$.

tert-Butyl 3-(4-nitrophenyl)prop-2-ynyl ether (4ed). Acetylene 4ed was prepared using a similar procedure to that for $\mathbf{4 a b}$, using 1-iodo-4-nitrobenzene (3d) (289.8 mg, $1.164 \mathrm{mmol}$ ),

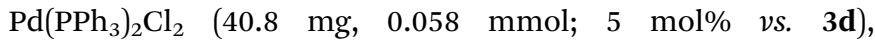
$\left(t-\mathrm{BuOCH}_{2} \mathrm{C} \equiv \mathrm{C}\right){ }_{4} \mathrm{Sn} \mathrm{1e}(180 \mathrm{mg}, 0.32 \mathrm{mmol}), \mathrm{Pr}_{2} \mathrm{NH}(1.6 \mathrm{~mL}$, $11.64 \mathrm{mmol})$ and BuOAc $(6 \mathrm{~mL})$. The reaction time was $5.5 \mathrm{~h}$. The resulting crude product was purified by column chromatography on a mixture of silica gel ( $6 \mathrm{~g}$ ) and silica gel modified with 3-aminopropyltriethoxysilane $\left(1 \mathrm{~g}, 1.14 \mathrm{mmol} \mathrm{g}^{-1}\right.$ of $\mathrm{NH}_{2}$ groups), and subsequently eluted with hexane and hexane: $\mathrm{HCCl}_{3}$ 9:1. The yield of acetylene 4ed was $132 \mathrm{mg}(49 \%)$, yellow crystalline solid. ${ }^{1} \mathrm{H}$ NMR $\left(400 \mathrm{MHz} \mathrm{CDCl}_{3}\right) \delta 1.30$ (s, 9H, $t \mathrm{Bu}), 4.34\left(\mathrm{~s}, 2 \mathrm{H}, \mathrm{OCH}_{2}\right), 7.57\left(\mathrm{~d},{ }^{3} \mathrm{~J}=9.2 \mathrm{~Hz}, 2 \mathrm{H}, \mathrm{Ar}\right)$, $8.16\left(\mathrm{~d},{ }^{3} \mathrm{~J}=9.2 \mathrm{~Hz}, 2 \mathrm{H}, \mathrm{Ar}\right) ;{ }^{13} \mathrm{C} \mathrm{NMR}\left(100 \mathrm{MHz}, \mathrm{CDCl}_{3}\right) \delta 27.5$, 51.0, 74.8, 83.0, 92.7, 123.5, 130.0, 132.4, 147.1. IR $\left(\mathrm{KBr}, \mathrm{cm}^{-1}\right)$ $\nu_{\max }$ 3105.8, 2976.5, 2862.7 (C-H, C-C), 2220.3 (C三C), 1593.4 $(\mathrm{C}=\mathrm{C}), 1342.6$ (symm NO $\left.\mathrm{N}_{2}\right)$. MS ( $\left.\mathrm{m} / \mathrm{z}, \mathrm{EI}, 70 \mathrm{eV}\right) 233\left(\left[\mathrm{M}^{+}\right], 0.3\right)$, $218\left(\left[\mathrm{M}-\mathrm{CH}_{3}\right]^{+}, 10.4\right), 160\left([\mathrm{M}-t \mathrm{BuO}]^{+}, 100\right), 57\left([t \mathrm{Bu}]^{+}, 60.5\right)$.

1-Hex-1-ynyl-4-nitrobenzene (4fd). Acetylene 4 fd was prepared using a similar procedure to that for $\mathbf{4 a b}$, using 1-iodo4-nitrobenzene (3d) (249.0 mg, $1.00 \mathrm{mmol}), \quad \mathrm{Pd}\left(\mathrm{PPh}_{3}\right)_{2} \mathrm{Cl}_{2}$ (35.1 mg, 0.05 mmol; 5 mol\% vs. 3d), $\left(\mathrm{CH}_{3} \mathrm{CH}_{2} \mathrm{CH}_{2} \mathrm{CH}_{2} \mathrm{C} \equiv \mathrm{C}\right)_{4} \mathrm{Sn}$ 1f $(121.9 \mathrm{mg}, 0.275 \mathrm{mmol}), \mathrm{Pr}_{2} \mathrm{NH}(1.37 \mathrm{~mL}, 10.0 \mathrm{mmol})$ and BuOAc $(6 \mathrm{~mL})$. The reaction time was $15 \mathrm{~h}$. The resulting product was purified by column chromatography over a mixture of silica gel (6 g) and silica gel modified with 3-aminopropyltriethoxysilane $\left(1 \mathrm{~g}, 1.14 \mathrm{mmol} \mathrm{g}{ }^{-1}\right.$ of $\mathrm{NH}_{2}$ groups). Hexane was used as the eluent. The column fractions were concentrated, the unreacted 1-iodo-4-nitrobenzene (3d) was filtered off, and the crude product was again purified under the same column chromatography conditions as previously to give $96.1 \mathrm{mg}(47 \%)$ of acetylene $\mathbf{4 f d}$ as a light yellow oil. ${ }^{1} \mathrm{H}$ NMR (400 MHz, $\left.\mathrm{CDCl}_{3}\right) \delta 0.96\left(\mathrm{t},{ }^{3} J=7.3 \mathrm{~Hz}, 3 \mathrm{H}, \mathrm{Me}\right)$, 1.44-1.53 (m, 2H, $\left.\mathrm{CH}_{2}\right), 1.58-1.65\left(\mathrm{~m}, 2 \mathrm{H}, \mathrm{CH}_{2}\right), 2.45\left(\mathrm{t},{ }^{3} \mathrm{~J}=\right.$ $\left.6.9 \mathrm{~Hz}, 2 \mathrm{H}, \mathrm{CH}_{2} \mathrm{C} \equiv\right), 7.51\left(\mathrm{~d},{ }^{3} J=8.7 \mathrm{~Hz}, 2 \mathrm{H}, \mathrm{Ar}\right), 8.15\left(\mathrm{~d},{ }^{3} J=\right.$ 8.7 Hz, 2H, Ar); $\left.{ }^{13} \mathrm{C} \mathrm{NMR} \mathrm{(100} \mathrm{MHz,} \mathrm{CDCl}_{3}\right) \delta$ 13.6, 19.3, 22.0, $30.5,79.3,96.8,123.5,131.3,132.3,146.6 . \mathrm{IR}\left(\mathrm{KBr}, \mathrm{cm}^{-1}\right) \nu_{\max }$ 3107.7, 3080.7, 2957.2, 2932.2, 2872.4 (C-H, C-C), 2230.0 $(\mathrm{C} \equiv \mathrm{C}), 1592.3(\mathrm{C}=\mathrm{C}), 1342.6\left(\operatorname{symm} \mathrm{NO}_{2}\right) . \mathrm{MS}(\mathrm{m} / z$, EI, $70 \mathrm{eV}) 203\left(\left[\mathrm{M}^{+}\right], 39.9\right), 188\left(\left[\mathrm{M}-\mathrm{CH}_{3}\right]^{+}, 58.3\right), 174\left(\left[\mathrm{M}-\mathrm{CH}_{2} \mathrm{CH}_{3}\right]^{+}\right.$, 6.6), $157\left(\left[\mathrm{M}-\mathrm{NO}_{2}\right]^{+}, 17.9\right)$.

Further details on the experimental procedures and spectra are given in the ESI. $\dagger$

\section{Acknowledgements}

VVD is grateful for financial support from the Russian Ministry of Education and Science (State Assignment to Higher Education Institutions, project no. 4.5547.2017/БЧ).

\section{Notes and references}

1 J. K. Stille, Angew. Chem., Int. Ed., 1986, 25, 508.

2 T. N. Mitchell, Synthesis, 1992, 803.

3 V. Farina, V. Krishnamurthy and W. J. Scott, Org. React., 1997, 50, 1.

4 P. Espinet and A. M. Echavarren, Angew. Chem., Int. Ed., 2004, 43, 4704.

5 C. Cordovilla, C. Bartolome, J. M. Martínez-Ilarduya and P. Espinet, ACS Catal., 2015, 5, 3040.

6 M. A. J. Duncton and G. Pattenden, J. Chem. Soc., Perkin Trans. 1, 1999, 1235.

7 M. Nath, Appl. Organomet. Chem., 2008, 22, 598.

8 I. J. Boyer, Toxicology, 1989, 55, 253.

9 E. Le Grognec, J.-M. Chrétien, F. Zammattio and J.-P. Quintard, Chem. Rev., 2015, 115, 10207.

10 M. Pereyre, J.-P. Quintard and A. Rahm, Tin in Organic Synthesis, Butterworths, London, 1986.

11 D. Young, in Tin Chemistry: Fundamentals, Frontiers, and Applications, ed. M. Gielen, A. Davies, K. Pannell and E. Tiekink, John Wiley \& Sons, Ltd, 2008, p. 653, ISBN: 978-0-470-51771-0.

12 R. A. Sheldon, Green Chem., 2007, 9, 1273.

13 W. J. Scott and A. F. Moretto, Tetraallylstannane, e-EROS Encyclopedia of Reagents for Organic Synthesis, Wiley, 2001.

14 X. N. Wei, L. Y. Liu, B. Wang, W. X. Chang and J. Li, Chin. Chem. Lett., 2009, 20, 40.

15 A. Yanagisawa, H. Inoue, M. Morodome and H. Yamamoto, J. Am. Chem. Soc., 1993, 115, 10356.

16 X. Zhang, R. Qiu, N. Tan, S. Yin, J. Xia, S. Luo and C.-T. Au, Tetrahedron Lett., 2010, 51, 153.

17 I. Pri-Bar, P. S. Pearlman and J. K. Stille, J. Org. Chem., 1983, 48, 4629.

18 R. M. Kamble and V. K. Singh, Tetrahedron Lett., 2001, 42, 7525 . 
19 M. Shi, R. Franks and K. M. Nicholas, in Advances in Chemical Conversions for Mitigating Carbon Dioxide. Studies in Surface Science and Catalysis, ed. T. Inui, M. Anpo, K. Izui, S. Yanagida and T. Yamaguchi, Elsevier Science B.V., 1998, vol. 114, p. 165.

20 A. S. Levashov, A. A. Andreev and V. V. Konshin, Tetrahedron Lett., 2015, 56, 1870.

21 A. A. Andreev, A. S. Levashov and N. V. Komarov, Method for preparing tri- and tetraorganylalkynyl tin, Pat. RU2317993, 2008.

22 A. S. Levashov, A. A. Andreev, D. S. Buryi and V. V. Konshin, Russ. Chem. Bull., Int. Ed., 2014, 63, 775.

23 P. Jaumier, B. Jousseaume and M. Lahcini, Angew. Chem., Int. Ed., 1999, 38, 402.

24 P. Jaumier, B. Jousseaume and M. Lahcini, Phosphorus, Sulfur Silicon, 1999, 150-151, 117.

25 B. Wrackmeyer and G. Kehr, J. Organomet. Chem., 1995, 501, 87.

26 B. Wrackmeyer, G. Kehr, A. Sebald and J. Kümmerlen, Chem. Ber., 1992, 125, 1597.
27 B. Wrackmeyer, G. Kehr and R. Boese, Angew. Chem., 1991, 103, 1374.

28 B. Wrackmeyer and G. Kehr, Polyhedron, 1991, 10, 1497.

29 M. Lahcini, P. M. Castro, M. Kalmi, M. Leskelä and T. Repo, Organometallics, 2004, 23, 4547.

30 W. P. Neumann and F. G. Kleiner, Liebigs Ann. Chem., 1968, 716, 29.

31 S. Lamandé-Langle, M. Abarbri, J. Thibonnet and A. Duchêne, J. Organomet. Chem., 2009, 694, 2368.

32 J.-H. Li, Y. Liang, D.-P. Wang, W.-J. Liu, Y.-X. Xie and D.-L. Yin, J. Org. Chem., 2005, 70, 2832.

33 E. Vedejs, A. R. Haight and W. O. Moss, J. Am. Chem. Soc., 1992, 114(16), 6556.

34 J. M. Brown, M. Pearson, J. T. B. H. Jastrzebski and G. van Koten, J. Chem. Soc., Chem. Commun., 1992, 1440.

35 P. Espinet and A. M. Echavarren, Angew. Chem., Int. Ed., 2004, 43, 4704.

36 W. Armarego and C. Chai, Purification of Laboratory Chemicals, Elsevier Science, Oxford, 2003, p. 608. 